\title{
Unusual rectal foreign body presenting as intestinal obstruction: a case report
}

\author{
İntestinal tıkanıklık şeklinde belirti veren alışılmamış rektal yabancı cisim: \\ Olgu sunumu
}

\section{Gaurav AGGARWAL, Bhaskar SATSANGI, Ramsharan RAIKWAR, Sumit SHUKLA, Raj MATHUR}

Colorectal foreign bodies are infrequently encountered, and are mostly associated with increased incidence of homosexuality and anal auto-erotism. The diagnosis may be confirmed by plain abdominal radiographs and rectal examination, but abdominal computerized tomography can be decisive in the further management. Manual extraction is only possible for very low-lying objects; patients with high-lying foreign bodies usually require a major intervention in the operation theater. An early decision of laparotomy should only be made after subjecting the patient to suitable investigations to determine exactly the localization of the object, in order to avoid any inadvertent damage to the adjoining vasculature as well as anal incontinence. We report the case of a young adult male who presented in the emergency department with an incarcerated, large, neglected rectal foreign body, a 'bull horn', causing intestinal obstruction. Emergent laparotomy was required for its removal.

Key Words: Anal auto-erotism; bull horn; neglected rectal foreign body.
Kolorektal yabancı cisimlere seyrek rastlanmakla birlikte çoğunlukla artan eşcinsellik ve anal otoerotizm insidansı ile ilişsilidir. Tanı, düz abdominal grafiler ve rektal inceleme ile doğrulanabilir, ancak bilgisayarlı karın tomografisi tedavide daha belirleyicidir. Elle çıkarma, yalnızca çok aşağı bölgede bulunan nesneler için mümkün olabilir; yukarı bölgede yabancı cisim bulunan hastalar, çoğunlukla ameliyathanede majör bir müdahale gerektirirler. Erken bir laparotomi kararı, nesnenin yerleşimini tam olarak belirlemek, komşu damar yapılara yönelik elde olmayan herhangi bir hasar ile birlikte anal inkontinans1 engellemek üzere yalnızca hastanın uygun incelemelere tabi tutulmasından sonra yapılmalıdır. Bu yazıda, acil servise, s1kışmış, büyük ve ihmal edilmiş rektal yabancı cisim (boğa boynuzu) nedenli bağırsak tıkanmasıyla başvuran genç bir erkek olgu sunuldu. Yabancı cismin çıkartılması için acil laparotomi yapıldı.

Anahtar Sözcükler: Anal oto-erotizm; boğa boynuzu; ihmal edilmiş rektal yabancı cisim.
Colorectal foreign bodies are infrequently encountered and are mostly in association with homosexuality and anal auto-erotism.

We report the case of a young adult male who presented in the emergency department with an incarcerated, large, neglected rectal foreign body, a 'bull horn', causing intestinal obstruction. Emergent laparotomy was required for its removal.

\section{CASE REPORT}

A 38-year-old male presented to the emergency department with complaints of abdominal pain and distention, feculent vomiting, and constipation with minimal passage of flatus for one week. His vital parameters were normal, apart from slight tachycardia; however, a digital rectal examination showed bloodstained mucus. Only on detailed questioning did the patient admit to self-insertion of a bull horn in the rec- 


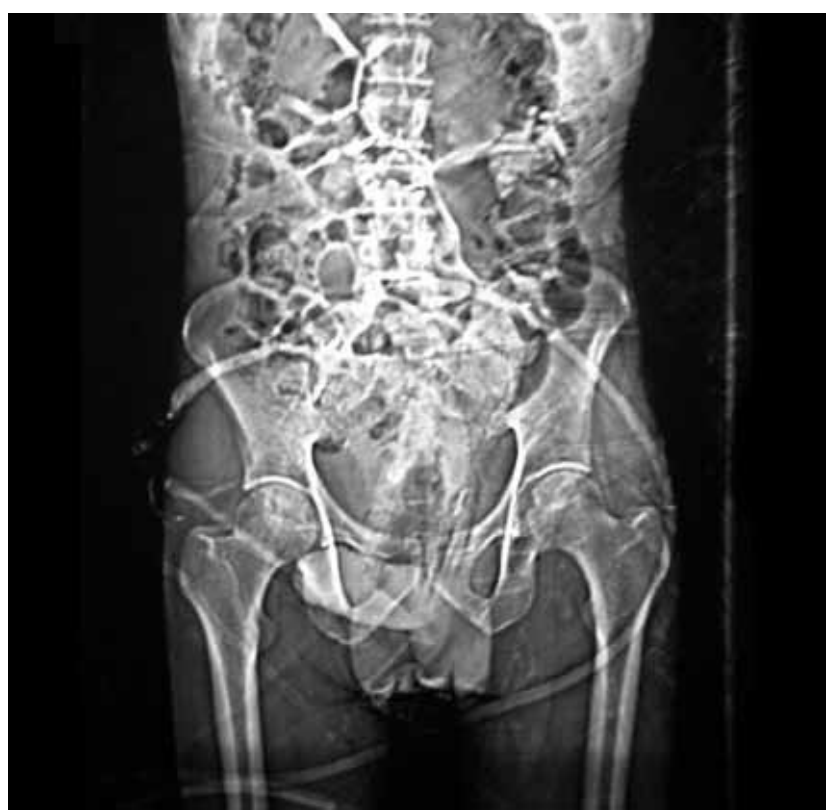

Fig. 1. Plain abdominal radiograph showing the dilated bowel loops and foreign body in the rectum.

tum two weeks before. A plain abdominal radiograph (Fig. 1) and abdominal computerized tomography (CT) scan (Fig. 2a, b) showed the bull horn impacted in the rectosigmoid region with proximally dilated bowel loops. There were no signs of perforation.

An emergency laparotomy was performed and the horn (Fig. 3) was removed through a longitudinal colotomy (Fig. 4). The colotomy was closed primarily and the postoperative period was uneventful. The patient is under regular follow-up, is continent and has had no problems in defecation. He was also given psy- chotherapeutic counseling so as to enable him to lead a normal social life.

\section{DISCUSSION}

Colorectal foreign bodies are infrequently encountered. Their presence is usually indicative of homosexuality, auto-erotism or a mentally unstable individual. Removal of retained foreign bodies can be a tedious process, requiring considerable skill and ingenuity on the part of the surgeon. ${ }^{[1-4]}$

The main reasons for the presence of foreign bodies include pruritus ani, accidental insertion, alleged assault, drug smuggling, iatrogenic (e.g. migration of colonic stents), and psychosexual motives. ${ }^{[5]}$ A wide variety of objects have been noted in the literature, including bottles, vibrators, fruits and vegetables, tools, and miscellaneous items such as light bulbs, candles, balls, and flashlights. ${ }^{[1,2,5-8]}$ The management of these cases varies from simple manual retrieval with or without general anesthetics or use of a sigmoidoscope, Foley's catheter or even cyanoacrylate adhesive attached to the object in order to aid its removal. ${ }^{[1,9]}$

A cattle horn as the rectal foreign body is quite rare, and is probably the fourth such case. ${ }^{[1]}$ Moreover, a rectal foreign body presenting further as bowel obstruction is an even rarer phenomenon. In this case, as the cattle horn was large and impacted high in the rectum, with a sharp serrated edge at the base (as clearly depicted by the CT scan), any manipulations through the transanal route could have caused rectal perforation or injury to the sphincter, with prolonged complications. Thus, an early decision for emergent laparotomy was taken and the horn was removed without incident.
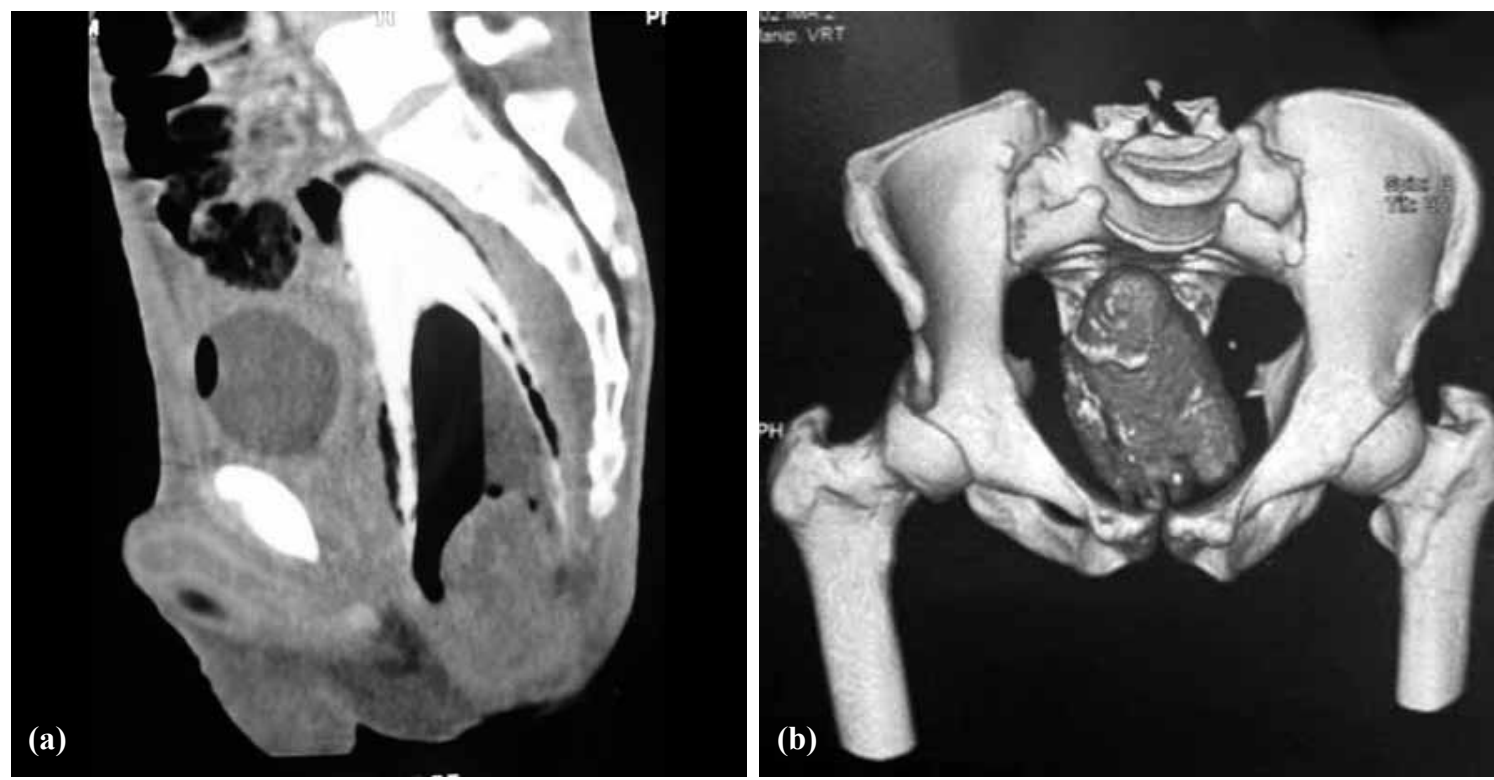

Fig. 2. (a) Sagittal view of the CT scan showing the high-impacted bull horn in the rectum. (b) 3-D reconstruction showing the rectal foreign body in situ. 


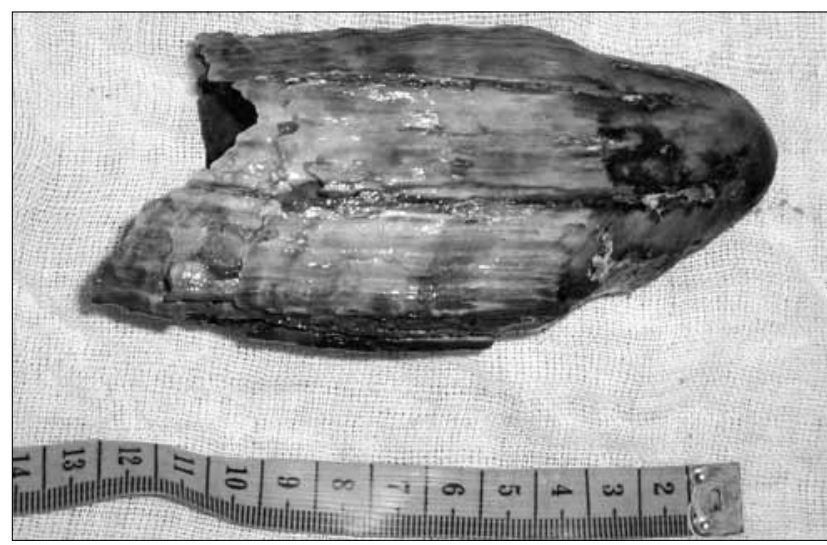

Fig. 3. The extracted rectal bull horn.

In addition to the surgical perspective, the role of psychologists cannot be understated, as such patients usually require extended counseling to enable them to lead a normal social and sexual life.

In conclusion, rectal foreign bodies are quite uncommon; however, most general surgeons will encounter such a patient at some point in their career. The diagnosis may be confirmed by plain abdominal radiographs and rectal examination, but a three-dimensional, abdominal CT can be decisive in the further management. Manual extraction is only possible for very low-lying objects; patients with high-lying foreign bodies usually require a major intervention in the operation theater. An early decision of laparotomy should be made only after subjecting the patient to suitable investigations in order to accurately localize the foreign body.

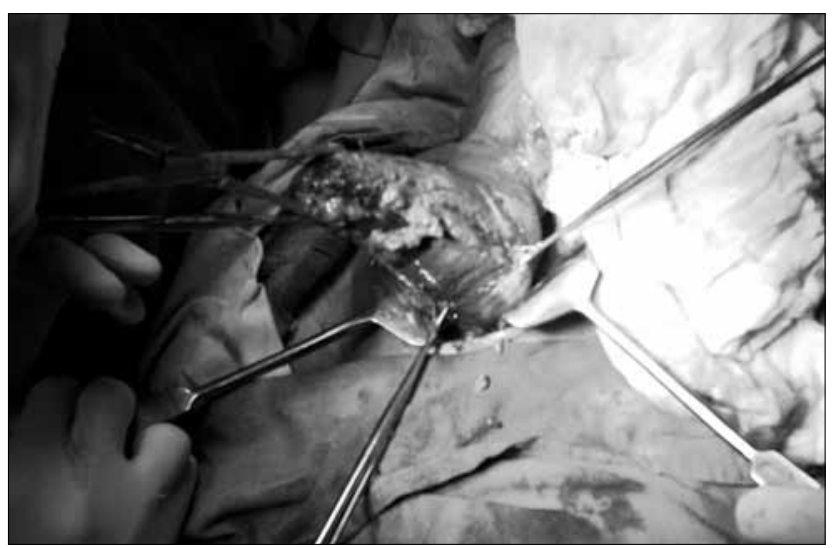

Fig. 4. The rectal bull horn being removed via a longitudinal colotomy.

\section{REFERENCES}

1. Busch DB, Starling JR. Rectal foreign bodies: case reports and a comprehensive review of the world's literature. Surgery 1986;100:512-9.

2. Couch CJ, Tan EG, Watt AG. Rectal foreign bodies. Med J Aust 1986;144:512-5.

3. Gould GM, Pyle W. Anomalies and curiosities of medicine. Philadelphia: W.B. Saunders; 1901. p. 645-8.

4. Schofield PF. Foreign bodies in the rectum: a review. J R Soc Med 1980;73:510-3

5. Kumar M. Don't forget your toothbrush! Br Dent J 2001;191:27-8.

6. Fuller R C. Foreign bodies in the rectum and colon. Dis Colon Rectum 1965;8:123-7.

7. Panasci EH, Zutrauen HA. A cucumber perforating rectosigmoid junction. Am J Proctol 1956;7:230-2.

9. Scamahorn MO. Unusual foreign body in the rectum. Am J Proctol 1956;7:499-502.

8. Eftaiha M, Hambrick E, Abcarian H. Principles of management of colorectal foreign bodies. Arch Surg 1977;112:691-5. 